


\section{Chapeuzinho no cinema contemporâneo: das páginas às telas e da ficção ao simulacro}

\section{Little Riding Hood in contemporary} cinema: from pages to screens and from fiction to simulacrum

\section{Larissa Lauffer Reinhardt Azubel'}

PORTO ALEGRE | v. 19 | n. 31 | 2014 | pp. 20-28 Sessões do Imaginário

\begin{abstract}
Resumo
No contexto baudrillardiano de esmaecimento e supressão da distância entre real e imaginário, de coincidência metonímica entre objetos e realidade, nos propomos a analisar o conto Chapeuzinho Vermelho em suas releituras no cinema contemporâneo. Primeiramente, refletimos sobre a função dos contos na sociedade e resgatamos suas origens. Em seguida, içamos as bases teóricas que sustentarão nossos argumentos na análise de Deu a Louca na Chapeuzinho e Deu a louca na Chapeuzinho 2. Enfim, recuperamos reflexivamente as origens orais e literárias do conto, para melhor compreendermos e explicarmos sua evolução hodierna na grande tela

Abstract

In the Baudrillardian context of fading and suppression of the distance between real and imaginary, and metonymic correspondence between objects and reality, we are proposing to analyse the tale Little Red Riding Hood in its rereadings in contemporary cinema. First, we reflect on the role of tales in society and rescue its origins. Then, we present the theoretical foundations that support our arguments in the analysis of Hoodwinked! and Hoodwinked Too! Finally, we reflexively recover the oral and literary origins of the tale, with the goal of understanding and explaining its evolution in cinema, particularly from the notions of simulacrum and involution of evil.
\end{abstract} particularmente a partir das noções de simulacro e de involução do mal.

\section{Palavras-chave}

Contos de fada; cinema; chapeuzinho vermelho; simulacro; invocação do mal.

\section{Keywords}

Fairy tales; cinema; little red riding hood; simulacrum; involution of evil. 


\section{Introdução}

As produções fantásticas, para Legros et al. (2007, p. 256), são meios de projeção dos nossos fantasmas, daquilo que nos atemoriza e seduz, representando "uma fonte de informação sociológica de grande importância"; pois, "colocam não apenas o homem diante de si mesmo, mas a sociedade diante de suas angústias e de sua dinâmica". Segundo Durand (2002) a função fantástica é universal, desempenhando, no ser humano, além do papel de refúgio afetivo, o de auxiliar na ação. De forma que, entendemos suas estruturas como bacias semânticas, reservatórios de valores fundamentais, presentes na cultura, sob a forma de apólogos, fábulas, mitos, lendas e contos.

Pensamos, num primeiro momento, sobre os contos de fada através da noção de "tecnologias do imaginário" de Silva (2012, p. 22). Tratam-se de "dispositivos (elementos de interferência na consciência e nos territórios afetivos além e aquém dela) de produção de mitos, de visões de mundo e de estilos de vida"; mas, não imposições, pois elas operam por meio da sedução e da adesão. Dão consistência ao etéreo, transformando a atmosfera de um tempo em corrente de uma época.

Com origem Celta, os contos estão ligados ao sobrenatural, ao mistério, à magia e à realização interior do ser humano (Coelho, 2000). Seu surgimento está vinculado às narrativas da Novelística Popular Medieval: "O sucesso das novelas arturianas prolongase pelo Renascimento adentro. São inúmeras as obras surgidas por volta do século XVI que mostram motivos ou sofrem influência da atmosfera mágica célticobretã" (Coelho, 1987, p. 64).

De tradição oral, eles atravessaram séculos e culturas adaptando-se de acordo com o estilo do tempo.

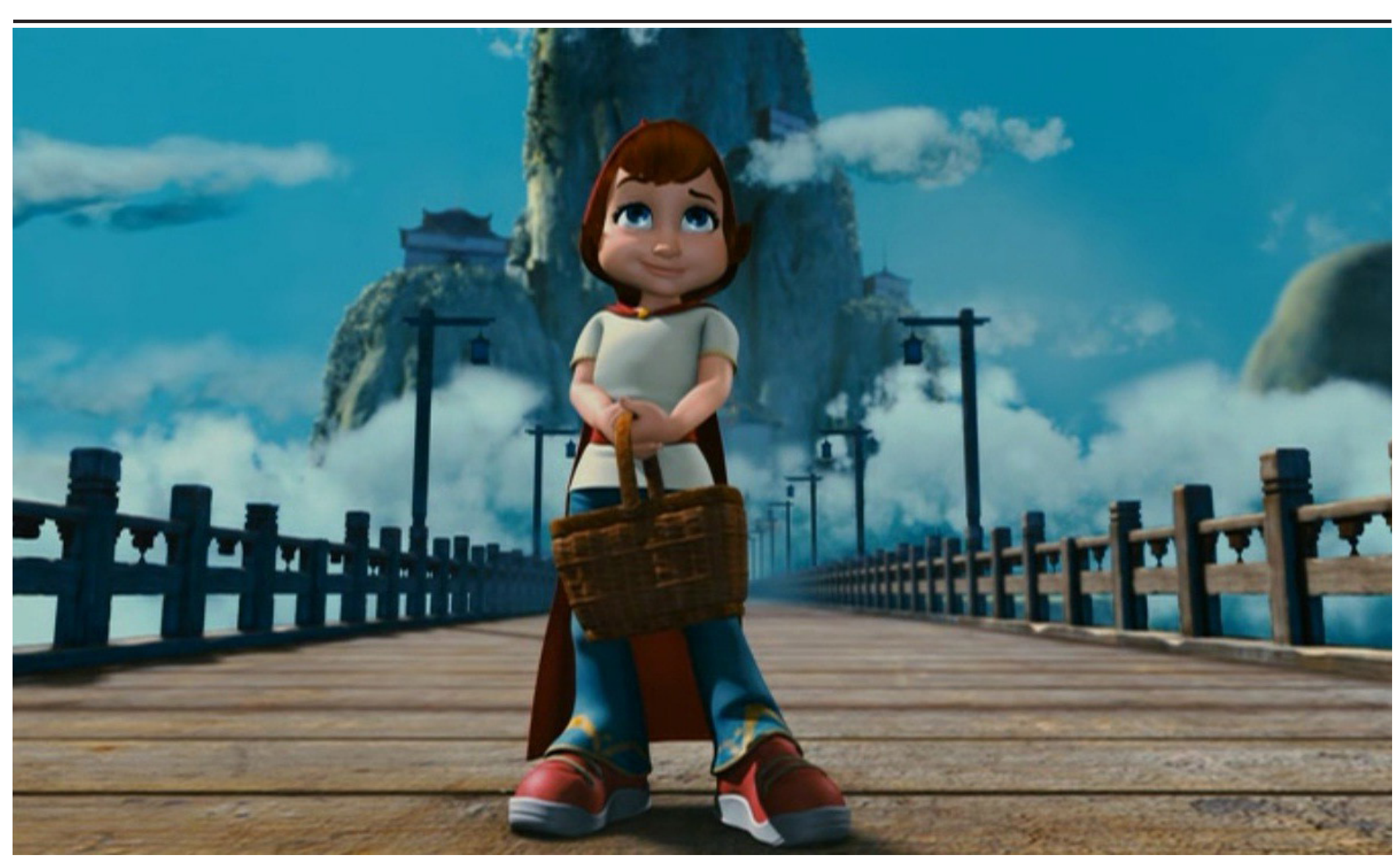

21 PORTO ALEGRE | v. 19 | n. 31 | 2014 | pp. 20-28 Sessões do Imaginário 
Os pregadores medievais, por exemplo, ilustravam argumentos morais em histórias que "retratavam um mundo de brutalidade nua e crua". Dessa forma, na

França do século XVIII, os contos costumavam abordar "do estupro e da sodomia ao incesto e ao canibalismo" (Darnton, 1996, p. 29).

Mas após a eclosão da Revolução Francesa e o período apocalíptico que se segue, "[...] abre-se uma nova era, a Romântica, quando se impõe uma nova razão" (Coelho, 1987, p. 71). Nesse momento, as fadas perdem espaço no mundo adulto, ficando restritas ao universo infantil. É nesse contexto que surgem os contos de Perrault e Grimm, distantes em mais de um século, mas próximos em motivos, episódios e personagens. Em ambos, predomina um tom de leveza que neutraliza os dramas e temores contidos nas narrativas. Ainda conforme a autora, nessas histórias, "[...] entre o real do cotidiano e o mistério do imaginário, desaparecem as fronteiras, mostrando a vida como algo muito difícil de ser enfrentado, mas, [...] extremamente valiosa e merecedora dos mais extremos sacrifícios" [sic] (Coelho, 1987, p. 75, grifo da autora). Porém o que acontece quando a distância entre o conto e a realidade se apaga? O imaginário esmaece e cede lugar ao simulacro. Assim, a proposta deste trabalho é pensar as versões cinematográficas contemporâneas do conto Chapeuzinho Vermelho - partindo das narrativas originais -, na era da simulação baudrillardiana.

\section{Simulacro e parte maldita no contexto pós-orgiástico baudrillardiano}

Buscamos em Baudrillard, nesse momento, elementos para pensar os contos em geral, mas, especialmente, Chapeuzinho Vermelho, na contemporaneidade. De maneira que, se faz necessário, situar um contexto de fala, qual seja, segundo o autor a "pós-orgia" da reprodução e da simulação. "Se fosse caracterizar o atual estado de coisas, eu diria que é o da pós-orgia. A orgia é o momento explosivo da modernidade, o da liberação em todos os domínios" (Baudrillard, 2001b, p. 9). Na política, no sexo, com relação às forças produtivas e destrutivas, à mulher à criança, ao inconsciente, à arte, etc. $\mathrm{E}$ o estado de simulação seria, portanto, aquele em que, numa espécie de indiferença total, "[...] só podemos repetir todas as cenas porque elas já aconteceram - real ou virtualmente [...]. Vivemos na reprodução indefinida de ideais, de fantasmas, de imagens, de sonhos" (Baudrillard, 2001b, p.10).

Segundo o autor, vivemos o desaparecimento dos signos não pelo fim ou pela morte, mas pelo excesso, pela proliferação e pela contaminação. Donde saturação e transparência, exaustão, epidemia e exterminação são palavras-chave para compreendermos o tempo hodierno. “O bem já não é perpendicular ao mal, nada mais se coloca em abcissas e ordenadas. [...] É o esquema peculiar ao fractal; é o esquema atual da nossa cultura" (Baudrillard, 2001b, p. 12). Substituímos a distância poética da metáfora pela contaminação profusa da metonímia, figura de linguagem de um contemporâneo imerso na indiferença, na desilusão e no desencanto.

Na ultrarrealidade, a problemática está, portanto, no excesso de diafaneidade, de superposição da informação, do conhecimento, das imagens, dos ruídos, etc. "Toda essa comunicação é no fundo apenas um enredo forçado, uma ficção ininterrupta que nos supre o vazio, o da tela tanto quanto o da nossa tela mental, do qual espreitamos as imagens com igual fascinação" (Baudrillard, 2001b, p. 19).

Vivemos, por conseguinte, a era da precessão dos simulacros, que o autor entende como um deserto do real. Na simulação (Baudrillard, 1991), o imaginário fica suprimido. Já não temos mais representações, mas hiper-realidades. Há uma sobrevalorização da verdade e "[...] quando o real já não é o que era, a nostalgia assume todo o seu sentido". Outrossim, vemos a "sobrevalorização dos mitos de origem e dos signos de realidade" (Baudrillard, 1991, p. 14), colocando os museus e a história na ordem do dia. Nesse mesmo sentido, os contos de fada ganham cada vez mais releituras. Quando "[...] tudo se metamorfoseia no seu termo inverso para sobreviver" (Baudrillard, 1991, p.29), eles abrem mão da magia e se atualizam na tecnologia: "Por toda a parte, hoje em dia, é preciso reciclar os detritos, os sonhos, os fantasmas; o imaginário histórico, feérico, lendário das crianças e dos adultos" (Baudrillard, 1991, p. 22).

As narrativas feéricas no ecrãs contemporâneos aparecem mais realistas e referenciais. Menos metafóricas e mais metonímicas, contaminadas por elementos da socialidade contemporânea. É importante ressaltarmos o seu retorno à esfera adulta. Animações e outros filmes com essa temática são cada vez menos estritamente "infantis", passaram ganhar a classificação indicativa "família".

Independentemente da faixa etária, precisamos de mitos que nos tranquilizem sobre nossos fins e os contos de fada atuam nesse sentido, preenchendo de significados os vazios e lacunas da existência. Essas narrativas podem ter sido, muitas vezes, rotuladas 
como infantis "[...] para fazer crer que os adultos estão noutra parte, no mundo 'real', e para esconder que a verdadeira infantilidade está em toda a parte" (Baudrillard, 1991, p. 21).

Por conseguinte, para Baudrillard (1991, p. 30), “[...] a ilusão já não é possível porque o real já não é possível. É todo o problema da paródia, da hiper-simulação ou da simulação ofensiva, que se coloca". Essa colocação nos remete a nosso objeto de estudo: releituras em tom paródico, transparentes, hiper-reais. Consonantes com "[...] a histeria característica de nosso tempo: histeria da produção e reprodução do real", na tentativa de ressuscitar o que Ihe escapa (Baudrillard, 1991, p. 34).

É no transbordar, na implosão do sentido que a simulação começa: "Absorção dos polos um no outro, curto-circuito entre os polos de todo o sistema diferencial de sentido, esmagamento dos termos e das oposições distintas, entre as quais a do medium e do real" (Baudrillard, 1991, p. 108, grifo do autor). A noção de mediação entra em xeque.

O meio é além da mensagem, o hiper-real - mais realista do que a própria realidade. Processa-se, dessa forma a invocação do simulacro, "[...] os objetos têm aí o brilho de uma hipersemelhança", a qual esvazia a representação, pois, "faz com que no fundo não se assemelhem senão a forma vazia da semelhança" (Baudrillard, 1991, p. 62).

O cinema nas suas tentativas atuais aproxima-se cada vez mais e com cada vez mais perfeição, do real absoluto, na sua banalidade, na sua veracidade, na sua evidência nua, no seu aborrecimento e, ao mesmo tempo, na sua presunção, na sua pretensão de ser o real, o imediato, o insignificado, o que é a empresa mais louca [...]. Nenhuma cultura teve jamais sobre os signos esta visão ingênua e paranoica, puritana e terrorista (Baudrillard, 1991, p. 64).

Vemos, assim, o realismo como uma neurose, obsessão do cinema, simulacro de simulação. E ele também se aproxima consigo, fascinado narcisisticamente por suas possibilidades: "[...] plagiase, recopia-se, refaz os seus clássicos, retroativa os mitos originais, refaz o mudo mais perfeito que o mudo de origem" (Baudrillard, 1991, p. 64). Outrossim, isso acontece com suas releituras dos contos de fada, objetos que ele repete, relê, (re) adapta e (re) eterniza.

As narrativas que nos propomos a analisar concernem, a este respeito, à terceira categoria de simulação baudrillardiana, a dos simulacros de simulação, "[...] baseados na informação, no modelo, no jogo cibernético - operacionalidade total, hiperrealidade" (Baudrillard, 1991, p. 151). Nesta, a distância entre real e imaginário está abolida e a hipersemelhança resulta de uma projeção desmedida, em que não há distinção entre a operação de gestão e a operação do real.

Já não é possível partir do real e fabricar o irreal, o imaginário a partir dos dados do real. O processo será antes o inverso: será o de criar situações descentradas, modelos de simulação e de arranjar maneira de lhes dar as cores do real, do banal e do vivido, de reinventar o real como ficção, precisamente porque ele desapareceu da nossa vida (Baudrillard, 1991, p. 154-155)
Para Baudrillard, há mais real na ficção do que na vida. O ficcional revitaliza, reatualiza e requotidianiza os fracta da simulação universal que é o real. Assim, a ficção não estaria mais nos ecrãs: "Já não está em lado nenhum e está por toda a parte, na circulação dos modelos, aqui e agora, na própria axiomática da simulação ambiente" (Baudrillard, 1991, p. 156). Não se distingue mais o real e o imaginário.

Quando a distância é abolida, só há o simulacro operacional. No pós-orgia, não há mais ilusão ou real, bem ou mal, certo ou errado, e superamos a adversidade dos adversários. Os dualismos são ultrapassados e "os dois polos diferenciais implodem um no outro - simultaneidade dos contraditórios, que é ao mesmo tempo a paródia e o fim de toda a dialética" (Baudrillard, 1991, p. 54).

Reciclando-se ao sabor do contemporâneo, parece também haver uma tendência de profilaxia nas narrativas feéricas, o que nos remete à noção baudrillardiana de transparência do mal: "Estamos em plena compulsão cirúrgica que visa a amputar os traços negativos das coisas e a remodelá-las idealmente por uma operação de síntese" (Baudrillard, 2001b, p. 52). Na reformulação e reprodução hodierna dos contos, desenham-se novos contornos, incorporam-se elementos mais pertinentes à atual socialidade.

Os contos perdem a aura para ganhar as telas e apaga-se o mal, faz-se a "grande faxina", uma vez que "a purificação é a atividade primordial" (Baudrillard, 1997, p. 41) em nossa sociedade, que "se empenha, então, em fazer com que tudo vá bem" (Baudrillard, 2001a, p. 36). Empenhamo-nos em suprimir a parte maldita (o estranho, o diferente, o outro, o negativo, o 
oposto, a morte, etc.): "Tornamo-nos muito fracos em energia satânica, irônica, polêmica, antagônica [...] a tal ponto temos medo do Mal, a tal ponto abusamos de eufemismos para não designar o Outro" (Baudrillard, 2001b, p. 90-91).

Em contrapartida, parecehaver maior complexidade dos perfis dos personagens. O mal não está mais onde se espera, está em todos os lugares - motivo pelo qual perdemos a capacidade de enunciá-lo. “Essa totalidade do Bem e do Mal nos supera, mas devemos aceitá-la totalmente. Não há inteligência das coisas fora dessa regra fundamental. A ilusão de fazer uma distinção entre os dois a fim de promover um só é absurda" (Baudrillard, 2001b, p. 117).

Ainda assim, para o autor, o mal não tem um princípio ligado à moral estritamente, mas reside no desequilíbrio e na vertigem, na complexidade, na estranheza, no que seduz, incompatibiliza, antagoniza, se faz irredutível. Faz-se, portanto, necessário, porque sem ele não há crise ou crítica, não há possibilidade de vida e de futuro. De modo que o "Outro" não existe para "ser exterminado, odiado, rejeitado, seduzido; ele é feito para ser compreendido, liberado, mimado, reconhecido" (Baudrillard, 2001b, p. 132) - enfim, aceito.

\section{Chapeuzinho: origens literárias e releituras cinematográficas}

O realismo era uma característica do conto original, segundo Darnton (1996), se considerarmos as histórias dos séculos XVII e XVIII, registradas por esse autor, com base na tradição oral camponesa, e por Perrault ([1697] 2012). Do século XIX ao começo do século $\mathrm{XX}$ as versões apareceram romantizadas, mais semelhantes às narrações dos irmãos Grimm ([18121822] 2008). Mas Chapeuzinho após a orgia, depois de deitar-se com o lobo, nunca mais seria a mesma. No século XVIII, começa uma espécie de "faxina" no conto. Hodiernamente, vemos a hiper-realização dos personagens (agora consonante com a sociedade da consumição) e percebemos que a transparência do mal se manifesta nas produções fílmicas.

De acordo com Darnton (1996) há registro de, pelo menos, 35 versões de Chapeuzinho Vermelho, no século XVIII. Segundo Coelho (2009), as fadas e o maravilhoso feérico estão em voga na literatura para adultos até o fim deste século. Dependendo do narrador e do público - se é contada na corte de Luís XIV ou numa moradia camponesa - há variações no nível de brutalidade. Mas o caráter moralizante sempre está presente. Há que se ressaltar que nessa época, na Europa, a visão que se tinha da infância não comportava a inocência e as crianças eram expostas à violência dos contos porque também a enfrentavam, em maior ou menor grau, no cotidiano. Vejamos parte de uma versão do conto que circulava oralmente naquele tempo:

- Olá, vovó. Trouxe para a senhora um pouco de pão e de leite.

- Sirva-se também de alguma coisa, minha querida. Há carne e vinho na copa.

A menina comeu o que era oferecido e, enquanto o fazia, um gatinho disse: "Menina perdida! Comer a carne e beber o sangue de sua avó!". Então o lobo disse:

- Tire a roupa e deite-se na cama comigo.

- Onde ponho meu avental?
- Jogue no fogo, Você não precisará mais dele.

Para cada peça de roupa - corpete, saia, anágua e meias - a menina fazia a mesma pergunta. E cada vez o lobo respondia:

- Jogue no fogo, Você não vai precisar mais dela.

Quando a menina se deitou na cama, disse:

- Ah, vovó! Como você é peluda!

- É para me manter mais aquecida, querida.

- Ah, vovó! Que ombros largos você tem!

- É para carregar melhor a lenha querida.

- Ah, vovó! Como são compridas as suas unhas!

- É para me coçar melhor, querida.

- Ah, vovó! Que dentes grandes você tem!

- É para comer melhor você, querida.

E ele a devorou.

(Darnton, 1996, p. 21-22).

Ao comentar este e outros contos da época, o autor, observa que eles acontecem em um mundo "[...] intensamente humano, onde peidar, catar piolhos, rolar no feno e jogar esterco um no outro são manifestações das paixões, valores, interesses e atitudes de uma sociedade camponesa hoje extinta" (Darnton, 1996, p. 77). Assim, pensamos que a noção de hiper-realidade seria pertinente também para a análise dos contos de séculos passados.

Mas, se por um lado, Chapeuzinho Vermelho, originalmente, já apresenta traços de simulação, por outro, ressaltamos que o mal é opaco, incontestável, forte e explícito na figura do lobo. Vemos os dualismos clássicos (bem x mal, caminho mais seguro $x$ caminho mais bonito, ingenuidade/estupidez $x$ perspicácia/inteligência) bem desenhados em 
questões pertinentes à sociedade da época, que vivia uma ambiência de medo, fome e negligência parental (Legros et al. 2007, p. 147).

Para Darnton (1996, p. 79), "[...] é a natureza inescrutável e inexorável de calamidade que torna os contos tão comoventes, e não os finais felizes que eles, com frequência, adquirem depois do século XVIII". Há o toque de fantasia, um lobo capaz de falar, de compor uma estratégia, de seduzir. Mas o realismo é pregnante e ilustra argumentos morais, como em Charles Perrault ([1697] 2012, p. 39-40), que adverte às mocinhas para não ouvirem todo o tipo de gente, não se deixarem levar pelos "lobos melosos", que chegam a "comer tantas" e "entre todos que há são os mais perigosos".

Registramos que o conto de Perrault, na coletânea Contes de ma Mère l'Oye ou Contos de Mamãe Gansa (1697) assemelha-se muito ao que citamos anteriormente. Termina igualmente com a menina devorada, mas é mais brando, pois não faz referência à prática de canibalismo. É, por conseguinte, na versão dos Irmãos Grimm, publicada na coletânea Kinderund Hausmaerchen ou Contos de Fadas para Crianças e Adultos (1812-1822), que surge a figura redentora do caçador, cujo papel assegura o final feliz.

Nessa variante, inclusive, a experiência de Chapeuzinho se repete, mas a menina e a avó já sabem como proceder e criam uma armadilha que mata o lobo. O mal é explícito e combatido. Mas também existe mal em quem é capaz de matar o mal encarnado. Se o dualismo bem/mal não parece tão bem resolvido, de outro modo, com a retirada das duas personagens femininas vivas da barriga do bolo, parece que a distância entre o conto e o real aumenta. Sendo este menos hiper-real do que os outros dois, há mais brecha para o imaginário, para a esfera da representação.

Até este momento, fizemos um resgate reflexivo das versões mais conhecidas como "originais" de Chapeuzinho Vermelho. Acreditamos que elas sejam referências importantes para o cerne de nosso processo de análise, que consiste em refletir sobre Deu a louca na Chapeuzinho (Hoodwinked!, Cory Edwards; Todd Edwards; Tony Leech, 2005) e Deu a louca na Chapeuzinho 2 (Hoodwinked Too! Hood vs. Evil, Mike Disa, 2011), que foram selecionados por serem os mais recentes filmes derivados do conto, com classificação livre e que se encaixam no gênero "família", ou seja, são voltados tanto às crianças como ao público adulto. Além disso, são considerados como "animação" e "comédia" 2 .

Percebemos que eles partem de uma desconstrução do conto e posterior reconstrução com elementos mais pertinentes ao contemporâneo. A história clássica tem sua alma retirada para ser preenchida com signos de uma hiper-realidade simulada, como verificaremos, a seguir.

Deu a Louca na Chapeuzinho, inicia com uma cena de suspense. Logo, entra a voz do narrador, dizendo que toda história tem sempre mais do que contam e se você quiser saber a verdade, tem que virar as páginas. Vemos, assim, a promessa de transparência do filme.

Na sequência, acontece a cena célebre, mas relida: a menina chega à casa da avó, quem a espera é o lobo com uma máscara. Quando ela desconfia, o lobo responde: "eu fiz uma plasticazinha". A menina percebe e ameaça pedir um mandado de segurança. Vemos nas duas situações uma contaminação do conto por questões hodiernas: a preocupação com a aparência e a possibilidade de obter proteção judicial. Elementos que hiper-realizam a narrativa.

De repente, a vovó sai amarrada do armário e o caçador surge quebrando a janela. Logo os policiais isolam a "cena do crime". Jornalistas entrevistam o chefe de polícia. Começa uma investigação para ver se o incidente tem a ver com o caso do bandido guloso, que furtou o mais famoso livro de receitas da floresta. Todos são suspeitos.

Do início ao fim da produção, os diálogos são carregados de expressões coloquiais e gírias e as cenas trazem elementos que remetem ao cotidiano contemporâneo. Diante disso, vemos a narrativa feérica estabelecer uma relação metonímica com a realidade. Chapeuzinho, por exemplo, pede um advogado. $\mathrm{O}$ inspetor Nick, surge na história, que "não pode acabar em pizza". Os quatro personagens centrais contam a sua versão dos fatos.

Conhecemos uma Chapeuzinho entregadora de doces, que canta frustrada: "Vem, me tira daqui, por favor, eu quero um novo mundo". Ela se lamenta "sou só uma menina", mas toma uma atitude para tentar salvar do bandido, ao menos, as receitas da sua família. Pega o livro sem permissão (furta) e se dirige à casa da avó quando encontra o lobo que a sonda. Assim, explica sua presença na cena inicial. Mais tarde, ela revela-se uma campeã de karatê, bem menos indefesa do que aparentava. Personagem complexa, a menina de capuz perde sua inocência, projeta angústias, nega o encanto, faz o mal visando o bem.

Ao ser interrogado, o lobo tenta esconder sua identidade: ele é um repórter e diz que sabe a verdadeira história. Tem uma coluna no jornal, “Fatos e contos de 
fadas", e passou os últimos meses, investigando o caso do bandido guloso. Desconfiado de Chapeuzinho, consultou suas fontes para saber mais sobre ela. $E$ foi por isso que a confrontou na floresta e na casa da avó. A figura do lobo sofreu uma profilaxia tal, que sua maldade ficou completamente apagada. Sobrou espaço apenas para alguma malícia, que não diz respeito ao seu "eu", mas à sua profissão. Comparando seu perfil e o de Chapeuzinho vemos que os dualismos esquemáticos foram superados e em suas figuras têm espaço para a simultaneidade de sentimentos e comportamentos contraditórios. Purificado, ele foi remodelado numa operação de amputação da parte maldita. Sobraram a ele apenas alguns eufemismos.

O lenhador, na verdade, é um ator e estava na floresta, ensaiando com o machado para fazer um comercial para calos nas mãos. Ele cortou uma árvore, que saiu rolando e da qual ele fugiu ladeira abaixo por isso entrou na casa quebrando a janela. Seu sonho era cantar em um grande coral e enquanto ele não conseguia uma oportunidade, vendia doces numa van. Interpretamos, a partir do foco nesse personagem um desencantamento da narrativa, que dá conta de uma literalidade atmosférica. Sobrevalorizando os signos de realidade, ele encarna o típico ser humano que sonha em ser célebre, mas vive uma rotina nada espetacular.

A vovó escondia da família seu lado de praticante de esportes radicais e mentia dizendo ser fã de novela. Ela explica sua posição na cena célebre por ter caído de paraquedas na lareira, se enrolado no equipamento e ido parar no armário. Há mais um sinal de perda aurática do conto, quando a relação entre ela e Chapéu é abalada, projetando os fantasmas e as crises possíveis em toda família. Além disso, lemos uma reciclagem do perfil da avó, relacionada com uma maior expectativa de vida e à histeria de viver intensamente. Assim, sustenta-se o entendimento de que os contos são referenciais nas telas hodiernas.

No cruzamento dos depoimentos, a polícia percebe que havia um ponto comum nas histórias: em algum momento todos haviam encontrado um suspeito coelhinho branco. Chapeuzinho, infiltrada, é a primeira a confrontar o bandido, que antes bancara o guru de autoajuda para um de seus comparsas. Mas ela fica refém do coelho, cujo objetivo era "ser o rei do pedaço", monopolizando o comércio de doces. Os demais personagens dominam a situação e vovó a salva.

O coelho como signo de maldade demonstra o quanto nos tornamos fracos em energia antagônica. A questão da autoajuda também dá peso à carga de hiper-real presente no filme. O tom paródico da história concerne a uma simulação intensiva, cujas situações diversas já pudemos ilustrar. Nelas reside o brilho da hipersemelhança com o real. Os modelos de simulação presentes na animação são pintados com as cores do cotidiano, do banal, do vivido, em suma, do real.

No fim, os verdadeiros bandidos são presos, a vovó e a menina fazem as pazes e o lobo publica tudo em sua coluna. Então, eles são convidados a trabalhar na organização secreta "Final Feliz para Sempre", onde devem proteger outros personagens e garantir a segurança do reino dos contos de fada. Entendemos, dessa forma, que foi superada a adversidade dos adversários. Bem e mal, certo e errado, não estão mais colocados em abcissas e ordenadas, mas andam juntos, dentro dos personagens, que se assemelham sobremaneira a pessoas reais. Seus temores e expectativas são os nossos. As dinâmicas de sua sociedade são as da nossa. O afastamento poético da metáfora foi substituído pela contaminação pragmática da metonímia. Como simulacro de simulação, o filme encurtou sobremodo a distância entre real e imaginário.

Deu a louca na Chapeuzinho 2 reúne "quatro heróis diferentes: Chapeuzinho Vermelho, a vovozinha, o lobo que não era mau, e um esquilo, que adorava cafeína, chamado Ligeirinho" - este já havia aparecido no primeiro filme, mas seu papel era secundário. Nick, o inspetor, adverte: "Não é só um conto de fadas, é uma aventura". Ao enfatizar que o lobo não é mau, vemos que o filme, reflexo e refletor da sociedade (considerando distorções), empenha-se na grande faxina que apaga os traços de negatividade do Outro.

Chapeuzinho começa o filme realizando um treinamento secreto com as "lendárias Irmãs do Capuz". A equipe, desfalcada, estava prestes a enfrentar um novo desafio: salvar duas crianças que estavam presas com uma bruxa numa casa de balinhas. A agência monitora a atividade da bandida com alta tecnologia. Vovó lidera a operação. Mas o lobo e Ligeirinho acabam agindo por conta própria. Lobo bate à porta da bruxa dizendo que é fiscal da prefeitura e que "é proibido morar numa sobremesa maior do que um bolinho". Exige o alvará e a lista de ingredientes.

Notamos, em diversos momentos que o filme enfatiza a tecnologia (perspectiva futurista), em detrimento da magia (perspectiva arcaica). Vemos que o conto de fada recicla-se no seu termo oposto para sobreviver. Como no filme anterior, constantemente, o banal é chamado ao conto, produzindo miniaturas do 
real. Vemos a referencialidade presente, por exemplo, na ação do lobo na cena recém mencionada.

Enquanto a polícia tenta invadir a casa, a bruxa foge numa vassoura turbinada com as crianças. Os três personagens a perseguem na moto da vovó, que acaba sendo também sequestrada. A menina, enquanto isso, é reprovada no teste das Irmãs e descobre a história da perigosa supertrufa-quem comê-lasetorna invencível. A receita some. Os dois acontecimentos estão conectados. Sequestraram a vovó para que ela cozinhasse o doce.

Mas o grupo descobre que João e Maria são os verdadeiros vilões. Eles usaram a bruxa para chegar até a vovó. Chapeuzinho e o lobo vão investigar o caso na cidade grande. Em busca dos vilões, interrogam o gigante do pé-de-feijão, sem sucesso: "Que bruxa, a minha sogra?". O coelho, que está preso, também está envolvido, é ele quem consegue os ingredientes secretos da receita. Temos assim, uma hibridização de histórias para dar conta do tempo presente heterogêneo: Chapeuzinho Vermelho, fortemente interligada a João e Maria, mas com referências a João e o pé de feijão, depois, aos Três Porquinhos e um momento de evocação do filme de suspense Hannibal (Ridley Scott, 2001).

Como no filme anterior, vemos nos vilões a involução da parte maldita. Neste, ela não está onde se espera e mais tarde se dissolve, em segundas chances para a bruxa e para os irmãos. Pela complexidade da narrativa, que envolve temas diversos, como limitações humanas e dificuldades de relacionamento, mas também, engodo, sequestro, vingança e extorsão, etc., compreendemos que os signos da animação abolem a distância entre o real e o representado. Não se trata de ficção ou de representação. Mas da paródia do cotidiano e dos dramas humanos, na releitura de um conto.

Chapeuzinho culpa o lobo pelos acontecimentos e ele se demite. Ligeirinho vai com ele por causa da carona. Diante das dificuldades de conseguir os ingredientes a bruxa desabafa com a vovó: "Sabe quanto custa um capanga? Eles têm sindicato, eu pago hora extra, plano de saúde, vale-transporte". Identificamos esse diálogo como ultrarreal, ele traz elementos fortes da questão trabalhista para história. Como em outras oportunidades, o que se revela no ecrã é antes o possível do que o impossível, o literal do que o metafórico. Vemos na ficção feérica familiar (infantil e adulta) um elogio do autêntico.

A tecnologia está presente a todo momento. Os personagens se comunicam por celular. Vóvó atualiza o status do Facebook para sequestrada. Os porcos tuitam que conseguiram vingarem-se do lobo, que na verdade consegue escapar. Ele tem uma crise de consciência e volta à agência para ajudar Chapeuzinho. Lemos, assim, um real reinventado como ficção, quanto à complexificação dos perfis, à não linearidade da história e ao reflexo de práticas culturais hodiernas.

Olenhador,que realizou o sonho de cantaréchamado para ajudar e leva consigo colegas, que antes eram mercenários. Ligeirinho e o lobo são pegos. Chapeuzinho cai numa armadilha e revela o ingrediente secreto das irmãs do capuz. As crianças declaram que fizeram um comercial há algumas semanas e vão fornecer a trufa para vilões do mundo inteiro, o que as tornará "podres de ricas". Traem a bruxa, que, em seguida, é salva pela vovó e se arrepende de suas maldades, passando para o lado do bem. $O$ enredo, nesse momento, revela desejos hiper-reais de ganhar dinheiro, de ter uma segunda chance, de se realizar profissionalmente. Dá conta do poder da propaganda na contemporaneidade e da importância da união para superar adversidades.

As crianças comem a trufa, ficam gigantes e ameaçam a cidade. A polícia chega e isola a área. $\mathrm{O}$ grupo de heróis se une para derrotá-las. Eles elaboram um plano estratégico, visto que, "uma trufa deixa você super, mas um monte deixa você redondo como uma bola". Logo, o recado é para a criançada não exagerar nos doces: "Vocês têm o direito de ficar em silêncio, tem direito a uma esteira e a comer brócolis"; "com a reabilitação e muitos exercícios vamos mostrar a essas crianças o caminho de casa". Notamos que o aspecto moral está presente no filme, que reflete à preocupação atual com a forma física e a saúde. E tudo termina bem, com uma parceria promissora entre as irmãs do capuz e a agência.

Sintetizando nossa percepção desse segundo filme, apontamos para uma estratégia narrativa em que o real esteve simulado por toda a parte. Quando não em sentido estrito, de cenas possíveis, em sentido amplo, de ambiência materializada em narrativa hiper-real. Complexidade foi palavra-chave para compreendermos a interação de personagens que encenaram o teatro da cultura hodierna. Com os signos de verossimilhança no ápice, vimos a criação de situações ficcionais coloridas a partir da palheta de cores da ultrarrealidade.

\section{Considerações finais}

Percebemos uma desmagicização na perda metafórica que notamos em ambos os filmes. A distância entre a história e o real, em nosso olhar, era 
curta nas versões apresentadas por Darnton e Perrault. Cresceu com a romantização do conto em Grimm e esmoreceu nos filmes contemporâneos analisados. Como elementos essenciais para o fortalecimento da relação metonímica entre o nosso objeto e a realidade, destacamos: a promessa de revelação da verdadeira história, a atualização e ambiguidade dos perfis, a complexificação dos enredos, as intrincadas relações estabelecidas entre os personagens, a profilaxia do conto e a transparência do mal, a incorporação de práticas, técnicas e hábitos hodiernos, e, a ausência de final feliz, mas promessa de vida que segue.

Chapeuzinho,Vovó,LoboeLenhadorapresentaram modos de viver, de ser, de sentir e de pensar hiper-reais e seus dramas se aproximaram daqueles das tramas da vida. Por conseguinte, o mágico subsistente disse respeito principalmente à apropriação das tecnologias pelos personagens e como elas auxiliaram no alcance de seus objetivos. Literais, (quando não em sentido estrito, em estilo e ambiência), as produções do século XXI apresentaram repertórios de reconhecimento das experiências. Assim, consideramos que os filmes analisados reforçaram o desnudamento do contemporâneo. $\mathrm{O}$ conto perdeu a aura para ganhar diafaneidade, desvelando a precessão dos simulacros no real deserto.

\section{Referências}

BAUDRILLARD, Jean. Simulacros e Simulação. Lisboa: Relógio d'água, 1991.

Senhas. Rio de Janeiro: Difel, 2001a.
A Transparência do Mal: Ensaios sobre os Fenômenos Extremos. São Paulo: Papirus, 2001b.

Tela Total: Mito-ironias da Era do Virtual e da Imagem. Porto Alegre: Sulina, 1997.

COELHO, Nelly Novaes. O Conto de Fadas. São Paulo: Ática, 1987.

Literatura Infantil: Teoria, Análise, Didática. São Paulo: Moderna, 2000.

O Conto de Fadas: Símbolos - Mitos Arquétipos. São Paulo: Paulinas, 2009

DARNTON, Robert. O Grande Massacre de Gatos. Rio de Janeiro: Graal, 1996.

DURAND, Gilbert. As Estruturas Antropológicas do Imaginário. São Paulo: Martins Fontes, 2002.

GRIMM, Jacob; GRIMM, Wilhelm. Contos de Grimm Obra Completa. Belo Horizonte: Itatiaia, 2008.

LEGROS, Patrick et al. Sociologia do Imaginário. Porto Alegre: Sulina, 2007.

PERRAULT, Charles. Contos de Mamãe Gansa. Porto Alegre: L\&PM, 2012.

SILVA, Juremir Machado. As Tecnologias do Imaginário. Porto Alegre: Sulina, 2012.

\section{Referências Audiovisuais}

KANBAR, Maurice; LOVEGREN, David; MONTGOMERY, Sue bea; STUTZMAN, Preston; EDWARDS, Cory; EDWARDS, Todd; LEECH, Tony. Hoodwinked!.[Filmevídeo]. Produção de Maurice Kanbar, David Lovegren, Sue Bea Montgomery e Preston Stutzman. Direção de Cory Edwards, Todd Edwards e Tony Leech. Estados Unidos, 2005. $80 \mathrm{~min}$. color. son.

KANBAR, Maurice; CAREY, Joan Collins; DISA,Mike. Hoodwinked Too! Hood vs. Evil. [Filme-vídeo]. Produção de Maurice Kanbare Joan Collins Carey. Direção de Mike Disa. Estados Unidos, 2011. 86 min. color. son.

LAURENTIIS, Dino; LAURENTIIS, Martha; SCOTT, Ridley. Hannibal. [Filme-vídeo]. Produção de Dino De Laurentiis, Martha De Laurentiis e Ridley Scott. Direção de Ridley Scott. Estados Unidos, 2001. 131 min. color. son.

\section{Notas}

1 Mestre e Doutoranda em Comunicação Social (PPGCOM/PUCRS - Av. Ipiranga, 6681 - Prédio 7, Sala 319, CEP: 90619-900, Porto Alegre - RS, Brasil). Bolsista CNPQ. E-mail: larissalauffer@gmail.com

2 De acordo com o site, imdb.com. Disponível em: <http://www.imdb.com/title/ tt0443536/?ref_=fn_al_tt_1>; e, <http://www.imdb. com/title/tt0844993/?ref_=fn_al_tt_1 $>$. Acesso em 10 jan. 2014 